\title{
Psychometric properties of the Brazilian version of the Pain Catastrophizing Scale for acute low back pain
}

\author{
Propriedades psicométricas da versão brasileira da Escala de Catastrofização da Dor \\ para dor lombar aguda
}

Renata Antunes Lopes ${ }^{1}$, Rosângela Corrêa Dias ${ }^{2,3}$, Bárbara Zille de Queiroz', Nayza Maciel de Britto Rosa', Leani de Souza Máximo Pereira ${ }^{3}$, João Marcos Domingues Dias ${ }^{2,3}$, Livia de Castro Magalhães

\begin{abstract}
Measurement instruments of pain catastrophizing for middle-aged and elderly individuals are needed to understand its impact on low back pain. The goals were to cross-culturally adapt the Pain Catastrophizing Scale, assess the construct validity through Rasch analysis, and verify reliability and convergent validity of pain catastrophizing with psychosocial factors. 131 individuals aged 55 years and older with acute low back pain were interviewed. The intra-rater reliability was $\mathrm{Kp}=0.80$ and interrater $\mathrm{Kp}=0.75$. The Rasch analysis found adequate reliability coefficients ( 0.95 for items and 0.90 for individuals). The separation index for the elderly was 2.95 and 4.59 items. Of the 13 items, one did not fit the model, which was justified in the sample evaluated. The pain catastrophizing correlated with most psychosocial factors. The instrument proved to be clinically useful. Subsequent studies should carry out the same analysis in different populations.
\end{abstract}

Keywords: low back pain, pain catastrophizing, elderly; Rasch analysis, validation studies.

RESUMO

Instrumentos de medida da catastrofização da dor para indivíduos de meia-idade e idosos são necessários para compreensão do impacto na dor lombar nessa população. Os objetivos foram adaptar transculturalmente a Escala de Catastrofização da Dor, avaliar a validade de construto pela análise Rasch, verificar a confiabilidade e a validade convergente da catastrofização da dor com fatores psicossociais. Participaram 131 indivíduos comunitários com 55 anos e mais com dor lombar aguda. A confiabilidade intra-examinadores foi de $\mathrm{Kp}=0,80 \mathrm{e}$ inter-examinadores $\mathrm{Kp}=$ 0,75. A análise Rasch, detectou adequados coeficientes de confiabilidade (0,95 para itens e 0,90 para indivíduos). 0 índice de separação dos idosos foi de 2,95 e dos itens 4,59. Dos 13 itens, um não se enquadrou no modelo, o que se justificou na amostra avaliada. A catastrofização da dor se correlacionou com a maioria dos fatores psicossociais. 0 instrumento mostrou-se clinicamente útil. Estudos subsequentes devem proceder às mesmas análises em diferentes populações.

Palavras-chave: dor lombar, catastrofização da dor, idosos, análise Rasch, estudos de validação.

Lower backpain(LBP)is one of the most commonhealth problems found among middle-aged and elderly people ${ }^{1,2}$. Evidence suggests that psychosocial factors, in addition to biomechanical factors, may influence pain levels and functional outcome ${ }^{3.4}$.

Psychosocial factors have been suggested as indicators of prognosis or obstacles for recovery from $\mathrm{LBP}^{5,6}$. There seems to be an interrelation between catastrophizing, pain, kinesiophobia, pain locus of control, depression and disability $^{1,2,3,4}$. Among the important psychosocial factors in the etiology and chronicity of lower back pain, pain catastrophizing stands out ${ }^{1,2,7}$. Pain catastrophizing is defined as a negative and exaggerated response to a given painful stimulus? ${ }^{7}$. There

*Universidade Federal de Minas Gerais - Belo Horizonte/MG - Brazil; Integrated Physiotherapy Clinics / Universidade de Itaúna - Itaúna/MG - Brazil.

${ }^{1}$ Universidade Federal de Minas Gerais, Departamento de Ciências da Rehabilitação, Belo Horizonte MG, Brazil;

${ }^{2}$ Universidade Federal de São Paulo, Departamento de Reabilitação, Sao Paulo SP, Brazil;

${ }^{3}$ Universidade Federal de Minas Gerais, Departamento de Fioterapia, Belo Horizonte MG, Brazil;

${ }^{4}$ University of Illinois, Occupational Therapist, Champaign Illinois, USA;

${ }^{5}$ Universidade Federal de Minas Gerais, Departamento de Terapia Ocupacional, Belo Horizonte MG, Brazil.

Correspondence: Renata Antunes Lopes; Rua Silva Jardim, 190 / ap. 301 - Centro; 35680-062 Itaúna MG, Brasil; E-mail: renataaa87@hotmail.com

Conflict of interest: There is no conflict of interest to declare.

Support: Conselho Nacional de Desenvolvimento Científico e Tecnológico (CNPq); Coordenação de Aperfeiçoamento de Pessoal de Nível Superior (CAPES);

Fundação de Amparo à Pesquisa do Estado de Minas Gerais (FAPEMIG).

Received 25 August 2014; Received in final form 13 December 2014; Accepted 02 January 2015. 
are three dimensions to this construct: rumination, which consists in the inability to inhibit thoughts related to pain; the augmentation of the displeasure of painful situations; and a sense of helplessness, hopelessness or inability to cope with painful situations ${ }^{7}$.

The Pain Catastrophizing Scale (PCS) developed by Sullivan et al. ${ }^{7}$, obtained good reliability and validity indexes. Sehn et al. ${ }^{8}$ translated and adapted the PCS for Brazilian individuals with migraines, fibromyalgia and chronic pain. The results showed good validity of the construct and adequate reliability inter-examiners. In spite of that, Hicks and Manal ${ }^{9}$ recommend that, for the safe use of the self-evaluation instruments in clinical or experimental environments, it is necessary to have an adequate process of transcultural adaptation and analysis of the psychometric properties of the instrument through its application on the sample to be used. It is known that instruments applied to young individuals may show different results from those applied to the elderly, in terms of validity and reliability, especially due to the psychosocial and physical peculiarities involved. Despite its impact on public health, LBP is insufficiently understood, especially among the middle-aged and elderly, who are normally excluded from the studies ${ }^{10}$. Furthermore, the biomechanical factors involved in chronic back pain are the most studied, in spite of their multifactorial etiology ${ }^{10}$.

In Brazil, a branch of the study Back Complaints in the Elders - BACE is being developed, including individuals over $55^{11}$. This study, among other constructs, will evaluate pain catastrophizing through the PCS which requires semantic and conceptual adjustments as well as an analysis of its psychometric properties for use in elderly with lower back pain.

Thus, the objectives of this study are to: proceed with the transcultural adaptation of the Brazilian version of the PCS, evaluate the validity of the construct through Rasch analysis, verify reliability of intra and inter-examiners as well as the convergent validity of pain catastrophizing with the intensity of the pain, locus of pain control, depressive symptoms, selfevaluationed kinesiophobia and disability and physical fitness of the target population.

\section{METHOD}

This is a methodological study with a subsample of the longitudinal multicentric international study about low back pain in the elderly - BACE "Back Complaints in the Elders", in progress $^{11}$.Ethics concern approved(0100.0.203.000-11-UFMG) and all participants signed a consent form.

A total of 131 individuals with acute low back pain but no cognitive impairment participated, recruited in a teaching clinic at Universidade Federal de Minas Gerais through an active screening of people in waiting rooms and by doctor referral.
The inclusion criteria were the same of BACE project: age of 55 or more, LBP of at least six weeks' duration, without having gone to health services with the same complaint in the past six months or more, characterizing a new back pain crisis ${ }^{11,12}$.

Excluded from the study were individuals with cognitive alterations detected by the Mini Mental State Examination $(\mathrm{MMSE})^{13}$ and/or some visual or hearing impairment which would prevent the performance of the tests (see more in BACE protocol ${ }^{11}$ ).

For the calculation of the sample, we considered an acceptable number of ten individuals for each item contained in the scale $(131)^{14}$.

The instruments used were:

Mini Mental State Examination: for cognitive tracking ${ }^{13}$. The cutoff points considered were 13 for illiterate individuals, 18 for those with up to 8 years of schooling, and 26 for individuals with over 8 years of schooling ${ }^{13}$.

Sociodemographic questionnaire: age, gender, color/race, marital status, formal education level.

Numerical Pain Scale: to measure intensity of the pain - 11 points, ranging from 0 (absence of pain) to 10 (extreme pain). Scale with good psychometric properties ${ }^{15}$.

Pain locus of control scale: to classify the perception of pain control. The components are: internal, chance, doctors and health professionals, and others. The adapted version shows good applicability and reliability ${ }^{16}$.

Center for Epidemiological Studies - Depression (CES-D): valid and reliable instrument for tracking symptoms of depression or vulnerability to depression in old age $\mathrm{e}^{17}$.

Tampa Kinesiophobia Scale: to measure the fear of movement. Consists of 17 questions and shows good applicability to individuals with back pain ${ }^{18}$.

Roland Morris Disability Questionnaire: instrument validated for Brazil, with 24 items about self-evaluationed disability due to back pain ${ }^{19}$.

Short Performance Physical Battery: valid and reliable instrument for evaluation of balance, gait speed, strength of lower limbs ${ }^{20}$.

The adaptation procedures followed those proposed by Herdman et al. ${ }^{21}$. According to them, conceptual equivalence ooccurs when they present the same idea; items equivalence refers to the adjustment of the elements in the original scale to represent the concept in question in the language in which the tool is to be applied; semantics equivalence is to transfer the meaning from one language to the other; operational equivalence is relative to the possibility of using a similar format of questionnaire, instructions, manner of application and metrics equivalence is to verify if the different versions reach similar levels in terms of validity and reliability ${ }^{21}$.

The semantic adaptation of the PCS followed four phases as proposed by Beaton et al. ${ }^{22}$ It consists in: (1) Translation into Portuguese by two independent translators; (2) Synthesis 
for a final version; (3) Back translation by two independent back translations; and (4) Expert committee formed to define the adjusted version. Details about the process are described below.

\section{Statistical analysis}

A descriptive analysis was carried out to characterize the profile of the sampling along all variables of the study.

The Kolmogorov Smirnov test was performed to verify the hypothesis of distribution normality of variable for the analysis of convergent validity.

The analysis of convergent validity between the PCS and other outcomes evaluated was performed with the Spearman Correlation Coefficient (r). The Quadratic Weighted Kappa Coefficient (Kp), considering the total number of agreements and disagreements inter and intra examiners, was used for the reliability analysis. To allow comparison with other studies, the Intraclass Correlation Coefficient (ICC) was also used ${ }^{23}$. All statistical tests were set at a significance of $\alpha=0.05$. The Vassarstats" software was used for the Quadratic Weighted Kappa Coefficient and the other analyses were conducted using the Statistical Package for Social Sciences (SPSS 17.0, Chicago, IL, USA).

The version of the tool adjusted for acute low back pain was submitted to a Rasch analysis, which allows the calibration of the difficulty of the items and the skill level of the individuals in a single continuum ${ }^{14,24}$. The basic assumption of the Rasch analysis, in the case of this study, is that, the higher the level of pain catastrophizing by the person, the greater their probability of getting higher scores in all the items of the scale (which reflect less or more catastrophizing) ${ }^{24}$. The analysis of the PCS was carried out using the program Winsteps 3.74.0, which calculates values such as $M n S q$ (goodness-of-fit), in the formats infit and outfit, and the value " $t$ " associated with this estimate, which indicate if the ratio between the level of catastrophizing of the individual and the difficulty of the item meet the assumptions of the model. Reasonable values to show the suitability of the items are: $M n S q=1 \pm 0.3$, with associated value of $t= \pm 2$ (). So, we chose Rasch analysis because its main contribution is related to the dependency relationship between the individual's ability and the probability of certain responses. Moreover, the map Rasch facilitates visual analysis of the distribution of individuals in relation to items. Further details about the Rasch analysis are described in Bond and Fox ${ }^{24}$.

\section{RESULTS}

\section{Characterization of the sample}

A total of 131 individuals participated in this study, with ages ranging between 55 and 85 . The other sociodemographic data are shown in Table 1.
Table 1. Sociodemographic characterization of participants $(n=131)$.

\begin{tabular}{llc}
\hline Variable & Mean (SD) & $\mathrm{n}(\%)$ \\
\hline Age & & $66.6(7.1)$ \\
Mender & Female & $121(92.3)$ \\
& Married & $60(45.8)$ \\
& Widow & $36(27.5)$ \\
& Single & $19(14.5)$ \\
Schooling & Divorced & $16(12.2)$ \\
& Incomplete basic & $59(45.3)$ \\
& education & \\
& Complete basic & $34(25.9)$ \\
& education & \\
& Complete high & \\
& school education & \\
Home & Complete college & \\
& education & $110(83.9)$ \\
\hline
\end{tabular}

SD: Standard deviation.

\section{Phases of the adaptation procedure \\ Evaluation of the equivalence between concepts and items}

The review of the literature showed the universality of the expression of pain catastrophizing, leading one to assume a conceptual equivalence, showing that the construct has the same conception in both English and Brazilian Portuguese. Likewise, we found that the elements contained in the scale are pertinent in any country or culture, representing an equivalence of items.

\section{Evaluation of semantic equivalence}

The semantic adaptation of the PCS for use in a population of middle-aged and elderly people with acute lower back pain consisted of four phases, described in Figure 1.

\section{Evaluation of operational equivalence}

It was recommended that the PCS be applied in the form of an interview, by trained examiners following standardized instructions, instead of a self evaluation, as proposed in the original version. The expert committee deemed that, since a large portion of the individuals among whom the scale was to be applied had low and/or heterogeneous schooling levels, the assisted application would avoid errors in interpretation. In order to check on the adjustments made by this committee, the scale was applied to 30 individuals ${ }^{24}$. These were shortly thereafter interviewed to verify their understanding. The pre-test showed a good comprehension on the part of the respondents and there was no need to return to the expert committee to make changes in the questions (appendix). Another 101 individuals were evaluated for the other analyses.

\section{Evaluation of the measurement equivalence}

After obtaining the minimum score necessary in the MMSE, the individuals were interviewed and submitted to 


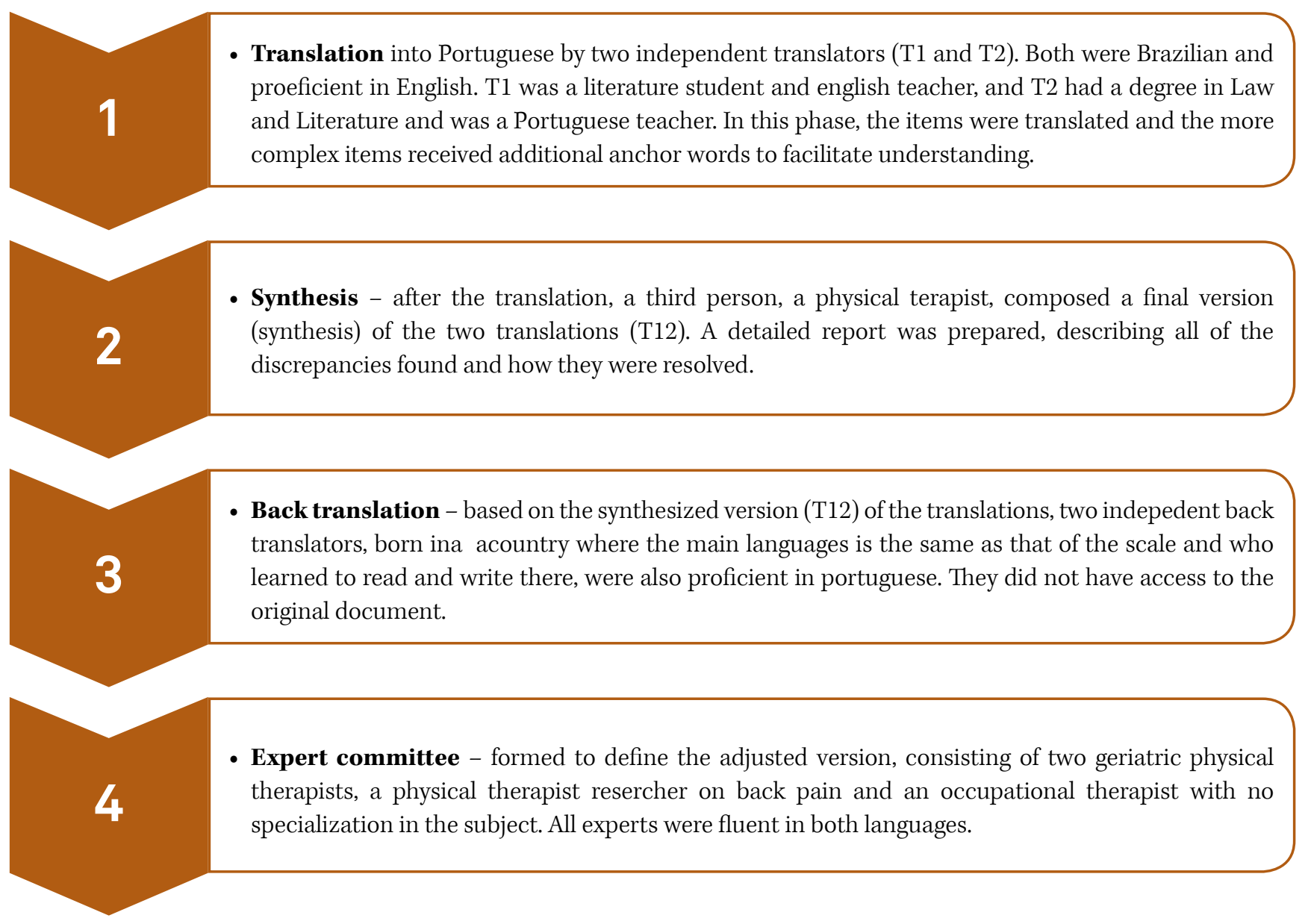

Figure 1. Phases of the semantic adaptation of the Pain Catastrophizing Scale (Beaton et al. ${ }^{22}$ ).

the functional tests during one day. After 7 to 10 days, the PCS was applied again by the same examiner to check on the intraexaminer reliability. For the analysis of the inter-examiner reliability, the same instrument was applied to the same individual by two different examiners on the same day. The validity of the construct and the convergence were evaluated and are described below.

\section{Analysis of the validity of the construct}

The result of the Rasch analysis is shown in Table 2, which breaks down the calibration or difficulty values of the items, MnSq (Infit and Outfit) and t. Of the 13 items of the PCS, only one (item 11 - "When I am in pain, I keep thinking how much I want the pain to stop") did not fit into the expectations of the model.

The item which represents the highest level of catastrophizing (greatest number of people answering 0), was item 7 - "When I am in pain, I keep thinking of other painful events (situations)", and the item with the lowest level of catastrophizing was number 11 - "When I am in pain, I keep thinking of how much I want the pain to stop". The separation index among individuals was 2.95 and among the items, 4.69 .
In Figure 2, the center line represents the continuum of catastrophizing, defined by the items organized hierarchically to the right and by the level of expression of the catastrophizing of the participants on the left. On the upper left, one can see the presence of a participant with a higher level of catastrophizing. On the bottom, one observes, likewise, a participant with a lower level of catastrophizing. One can also observe that most of them are aligned with moderate to high levels of catastrophizing. As expected, few individuals are located in the upper and lower part of the continuum, with no ceiling or floor effect being found. Most were distributed in the middle third of the continuum, characterizing a moderate level of catastrophizing. The analysis of the score patterns indicates that the option "not at all" was used in $18 \%$ of the replies, "light" in $14 \%$, "moderate" in $24 \%$, "intense" in $17 \%$ and "always" in $27 \%$.

\section{Reliability}

For the reliability analysis, the sampling considered was of 50 individuals. After 7 to 10 days, the PCS was applied again by the same examiner to check on the intraexaminer reliability. For the analysis of the inter-examiner reliability, the same 
Table 2. Pain Catastrophizing Scale Calibration Items of the adjusted version according to Rasch Analysis $(n=131)$.

\begin{tabular}{|c|c|c|c|c|c|c|c|}
\hline & Item & Metrics & Standard error & Infit MnSq & $\mathrm{t}$ & Outfit Mnsq & $\mathrm{t}$ \\
\hline 7 & I keep thinking of other painful events. & 0.71 & 0.09 & 1.16 & 1.3 & 1.07 & 0.5 \\
\hline 12 & There is nothing I can to do reduce the intensity of the pain. & 0.44 & 0.09 & 1.10 & 0.8 & 1.13 & 0.9 \\
\hline 3 & It's terrible and I think it's never going to get any better. & 0.33 & 0.09 & 1.03 & 0.3 & 1.12 & 0.8 \\
\hline 2 & I feel I can't go on living like this. & 0.32 & 0.09 & 1.23 & 1.8 & 1.18 & 1.2 \\
\hline 5 & I feel I can't stand it anymore. & 0.19 & 0.09 & 0.93 & -0.6 & 0.86 & -0.9 \\
\hline 1 & I worry all the time about whether the pain will end. & 0.06 & 0.09 & 0.98 & -0.1 & 1.28 & 1.8 \\
\hline 9 & I can't stop thinking about the pain. & 0.04 & 0.09 & 0.75 & -2.2 & 0.86 & -0.9 \\
\hline 10 & I keep thinking about how much it hurts. & 0 & 0.09 & 0.73 & -2.4 & 0.85 & -1 \\
\hline 13 & I wonder whether something serious may happen. & -0.01 & 0.09 & 1.19 & 1.5 & 1.04 & 0.4 \\
\hline 6 & I become afraid that the pain will get worse. & -0.14 & 0.09 & 0.97 & -0.2 & 0.87 & -0.9 \\
\hline 4 & It is awful and I feel that it overwhelms me. & -0.23 & 0.09 & 0.82 & -1.5 & 0.77 & -1.6 \\
\hline 8 & I anxiously want the pain to go away. & -0.73 & 0.1 & 0.92 & -0.6 & 0.86 & -0.8 \\
\hline 11 & I keep thinking about how much I want the pain to stop. & -0.99 & 0.11 & 1.35 & 2.3 & 1.38 & 1.9 \\
\hline
\end{tabular}

instrument was applied to the same individual by two different examiners on the same day. The result of the intraexaminer reliability was $\mathrm{Kp}=0.80 \pm 0.01(95 \% \mathrm{CI}=0.77-0.82)$ and the ICC was $0.88(95 \% \mathrm{CI}=0.87-0.90)$. The interexaminer reliability was $\mathrm{Kp}=0.75 \pm 0.01(95 \% \mathrm{CI}=0.72-0.78)$ and ICC $=0.77(95 \% \mathrm{CI}=0.73-0.80)$.

\section{Convergent validity}

The correlations between pain catastrophizing and the other constructs evaluated are shown in Table 3.

\section{DISCUSSION}

The adjusted version of the PCS was validated for elderly Brazilians with acute lower back pain and presented psychometric characteristics equivalent to the other versions ${ }^{8,25,26}$.

With regard to the sample characteristics, the constitution was mainly feminine (92.3\%). Considering that the sample was random at the health center, this corroborates the trend towards feminization of aging and quest for health care $^{27}$. The representation of taking care of one's self as a woman's task, the issues related to work, the difficulty of access to health services and the lack of units specifically focused on men's health, are some of the reasons given by the individuals to explain the lower demand for health services ${ }^{27}$.

Of the 13 items of the PCS, only one (item 11 - "When I am in pain, I keep thinking of how much I want the pain to stop") did not reflect the expectations of the model, which was considered acceptable, according to the assumptions of the Rasch analysis. This item presents a more complex grammatical construction, which may have contributed to misunderstanding by some individuals. Upon examining the scores for this item, we found an unexpected reply given only by three individuals. One of the elderly, a 61 year old woman, was not in pain at the moment of evaluation, which may have led to a memory bias and inconsistency in the reply, as reported by Maric et al. ${ }^{28}$. Furthermore, the three elderly women in question were aged 61, 68 and 76, with a low schooling level, which may have contributed to their difficulty in understanding this more complex item, as reported by Teixeira-Salmela et al. ${ }^{14}$.

The indexes of separation of items and of individuals showed that the scale is able to divide the people into approximately three levels of catastrophizing (low, medium and high), as described by Fernandes et al. ${ }^{25}$ and five levels of expression of catastrophizing.

The calibration of the items (0.95) and the individuals (0.91) indicated stability and good internal consistency, which means that the answers of the individuals were also quite reliable, and as a result the measures can be reproduced in subsequent applications ${ }^{23}$.

The average level of pain catastrophizing was $29.2( \pm 13.1)$ points, corroborating the results of other versions ${ }^{26,29}$ and going against those of Fernandes et al. ${ }^{25}$. In this study, the average level was 14 points, but the population was of young adults with subacute lower back pain, which may have led to different results. We wish to point out that we did not find any analysis study of the psychometric properties of the PCS for other populations with samplings of elderly with acute lower back pain, especially Rasch analysis, thus making it difficult to compare the data.

The expectation of the Rasch model is for there to be a rising order in the use of the scores, which did not happen, generating a small distortion in the use of category 3 (intense), which seems to be more difficult to be used than categories 2 (moderate) and 4 (always). It was expected that the percentage of "always" answers would be lower than $27 \%$, remaining at $17 \%$ or less. One of the hypotheses is that the individuals found it more familiar and easier to answer "always" than "intense", especially for those who had fewer years of formal education, true for most of the respondents. Another hypothesis is that the participants were in doubt because the answers "intense" and "always" are two different categories of words: the first refers to intensity, and the second to frequency. In the study of Meyer et al. ${ }^{29}$ of adaptation of the PCS to German, this observation 
Greater cat. Subjects + Items Greater cat.

3

$\mathrm{X}+$

$\mathrm{X} \mathrm{T} \mid$

$\mathrm{X}$

2

$\mathrm{xx}+$

$\operatorname{XXXXXX}$

$\operatorname{XXXXXXXX}$

$\mathrm{XX}$

Si

$\mathrm{XXX}$

$\mathrm{XXX}$

$\operatorname{XXXXX}$

$\begin{array}{lll}\operatorname{XXXXXX} & \mathrm{T}\end{array}$

$\operatorname{XXXX} \mid 7$. I think of painful events

$\operatorname{XXXX} \quad$

XXXXXXXXXXXXX IS 12. Nothing diminishes the pain

XXXX | 2. I cant go on 3. Awful, never improves

$\operatorname{XXXXXXXXXM|} 5$. I cant stand it anymore

XXXXXXXXXXXX | 1 . I get worried

$0 \quad X X X+M$ 10.I think of how much it hurts. 13. Something serious will happen 9. Cant stop thinking of pain

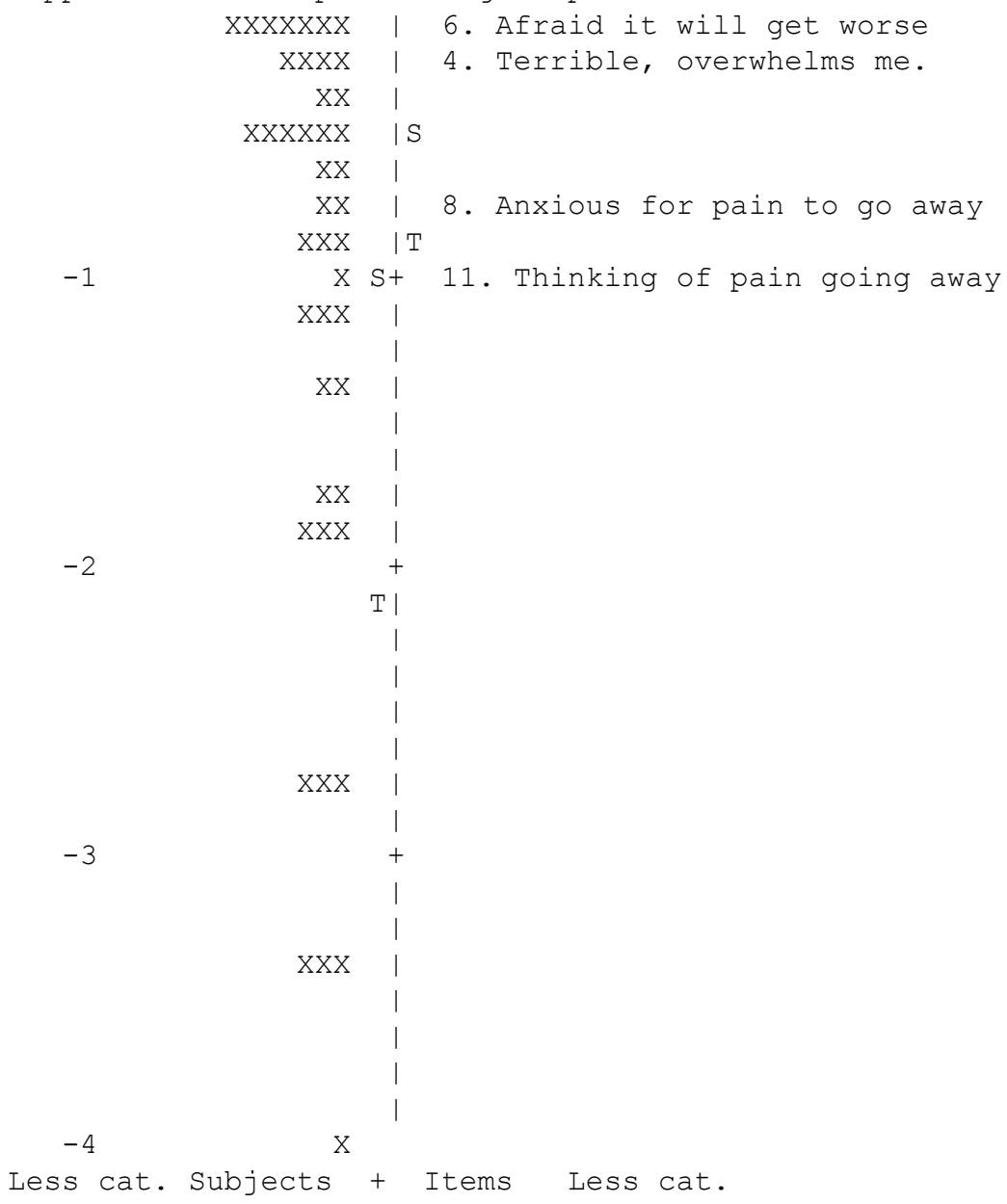

Greater cat.: Greater catastrophizing; Less cat.: Less catastrophizing.

Figure 2. Representative map of individuals performance regarding levels of catastrophizing expressed in items of the Rasch analysis $(n=131)$. 
Table 3. Correlation among pain catastrophizing, pain intensity, depressive symptoms, pain locus of control, kinesiophobia, self-reported incapacity and physical capacity.

\begin{tabular}{|c|c|c|c|c|c|c|c|c|c|}
\hline $\mathrm{PCS}^{\mathrm{a}}$ & END $^{b}$ & CES-D ${ }^{c}$ & LCD_INT ${ }^{d}$ & LCD_ACA & LCD_MED ${ }^{f}$ & LCD_OUTg & ETC $^{h}$ & SPPBi & $\mathrm{RM}^{\mathrm{j}}$ \\
\hline rho & $\star \star 0.256$ & $* \star 0.357$ & 0.02 & $\star \star 0.332$ & 0.074 & $\star * 0.342$ & $* \star 0.363$ & $*_{-0.203}$ & $\star * 0.403$ \\
\hline$p$ & 0.003 & $<0.01$ & 0.754 & $<0.01$ & 0.4 & $<0.01$ & $<0.01$ & 0.022 & $<0.01$ \\
\hline
\end{tabular}

aPCS: Pain Catastrophizing Scale; ${ }^{b} E N D:$ Numeric Pain Scale; ${ }^{\circ}$ CES-D: Center for Epidemiological Studies - Depression; ${ }^{\mathrm{L} L C D}$ _INT: Locus Pain Control - Internal; 'LCD_ACA: Locus Pain Control - Chance; fLCD_MED: Locus Pain Control - Others; \&LCD-OUT: Locus Pain Control - Others; ${ }^{\text {} E T C: ~ T a m p a ~ K i n e s i o p h o b i a ~ S c a l e ; ~ ' S P P B: ~ S h o r t ~ P e r f o r m a n c e ~ P h y s i c a l ~ B a t t e r y ; ~ ' R M: ~ R o l a n d ~ M o r r i s ~ D i s a b i l i t y ~}$ Questionnaire. ${ }^{\star} p<0.05 ;{ }^{*} p<0.01$.

was also made and the option of answers was altered. In spite of this, in the present study, in a discussion of the expert committee, they did not believe it necessary to make any changes in the options of the answers, other than a simple translation, since the original scale had already been developed and applied that way. During the Rasch analysis, an attempt was made to group the "intense" and "always" categories, seeking to improve the behavior of the scale, but this procedure did not modify the distortion pattern in the use of the score categories. Future studies will probably verify if the change of the name of the category will result in a lesser distortion in the use of the categories and a better quality of the metrics.

The intra and inter examiner reliabilities were considered through the weighted Kappa Coefficient as substantial, and by the Intraclass Correlation Coefficient as high, thus corroborating previous results ${ }^{26,29}$. These results support the replicability of the Brazilian version of the adjusted PCS.

Pain catastrophizing correlated with all evaluated constructs, except control of locus of internal pain and among doctors and health professionals, corroborating previous results $^{26,29}$ (Table 2). The correlations were considered moderate and weak, showing that, although the constructs are close, they are not redundant. According to Vlaeyen et al. ${ }^{30}$, the individuals who catastrophize their pain tend to have more kinesiophobia and greater disability ${ }^{7}$ When they are depressed and disabled, the chances of heightened catastrophization are greater, generating a vicious cycle ${ }^{7}$.
In conclusion, the results showed that the version of Pain Catastrophizing Scale ajusted for the middle-aged and elderly population with acute low back pain presented a good understanding of the items by the respondents and presented adequate psychometric properties.

Analyzing the erratic pattern of item 11, it is recommended that, in future studies, the behavior of this item be monitored to check if the problems observed in this study will persist in other population groups. Should this occur, it is necessary to consider the possibility of revision, replacement or exclusion. One should also monitor the use of the score categories to see if there is any need to adjust the name in the option of "intense" score.

It is important to point out the importance of the option of applying this sort of tool by an examiner and not on a self-evaluation basis, for most of the current population of elderly who seek medical care at the health clinics present a low level of formal education, which can interfere in the interpretation of the questions, compromising the reliability of the responses.

It is recommended that the interviewer reinforce the initial instructions assuring that the individuals understand the question, avoiding inconsistencies in the responses. Furthermore, in subsequent studies, the PCS-B should be applied on other types of samplings so that the clinimetric validity and quality of the tool is better investigated and expanded.

\section{References}

1. Shi Y, Hooten WM, Roberts RO, Warne DO. Modifiable risk factors for incidence of pain in older adults. Pain. 2010;151(2):366-71. http://dx.doi.org/10.1016/j.pain.2010.07.021

2. Hoy D, Brooks P, Blyth F, Buchbinder R. Best Pract Res Clin Rheumatol. 2010;24(6):769-81. http://dx.doi.org/10.1016/j.berh.2010.10.002

3. Rudy TE, Weiner DK, Lieber SJ, Slaboda J, Bosto JR. The impact of chronic low back pain on older adults: a comparative study of patients and controls. Pain. 2007;131(3):293-301. http://dx.doi.org/10.1016/j.pain.2007.01.012

4. Quartana PJ,Campbell CM, Edwards RR. Pain catastrophizing: a critical review. Pain catastrophizing: a critical review. Expert Rev Neurother. 2009;9(5):745-58. http://dx.doi.org/10.1586/ERN.09.34

5. Foster NE, Delitto A. Embedding psychosocial perspectives within clinical management of low back pain: integration of psychosocially informed management principles into physical therapist practice-challenges and opportunities. Phys Ther. 2011,91(5):790-803. http://dx.doi.org/10.2522/ptj.20100326

6. Linton SJ. Do psychological factors increase the risk for back pain in the general population in both a cross-sectional and prospective analysis? Eur J Pain. 2005,9(4):355-61. http://dx.doi.org/10.1016/j.ejpain.2004.08.002

7. Sullivan MJ, Bishop SR, PivikJ. The Pain Catastrophizing Scale: development and validation. Psychol Assess. 1995;7(4):524-32. http://dx.doi.org/10.1037/1040-3590.7.4.524

8. Sehn F, Chachamovich E, Vidor LP, Dall-Agnol L, Souza ICC, Torres ILS et al. Cross-cultural adaptation and validation of the Brazilian Portuguese version of the pain catastrophizing scale. Pain Medicine. 2012;13(1):1425-35. http://dx.doi.org/10.1111/j.1526-4637.2012.01492.x

9. Hicks GE, Manal TJ. Psychometric properties of commonly used low back disability questionnaires: are they useful for 
older adults with low back pain? Pain Med. 2009;10(1):85-94. http://dx.doi.org/10.1111/j.1526-4637.2008.00548.x

10. Preuper HRS, Reneman MF, Boonstra AM, Dijkstra PU, Versteegen GJ, Geertzen JHB et al. Relationship between psychological factors and performance-based and self-evaluationed disability in chronic low back pain. Eur Spine J. 2008;17(11):1448-56. http://dx.doi.org/10.1007/s00586-008-0772-0

11. Scheele J, Luijsterburg PAJ, Ferreira ML, Maher CG, Pereira L, Peul WC et al. Back complaints in the elders (BACE); design of cohort studies in primary care: an international consortium. BMC Musculoskelet Disord. 2011;12:193. http://dx.doi.org/10.1186/1471-2474-12-193

12. Tulder M, Becker A, Bekkering T, Breen A, Real MTG, Hutchinson A et al. European guidelines for the management of acute nonspecific low back pain in primary care. Eur Spine J. 2006;15(2 Suppl):S169-91. http://dx.doi.org/10.1007/s00586-006-1071-2

13. Bertolucci PHF, Brucki SMD, Campacci SR, Juliano Y. O mini-exame do estado mental em uma população geral: impacto da escolaridade. Arq Neuropsiquiatr. 1994;2(1):1-7.

14. Teixeira-Salmela LF, Magalhães LC, Souza AC, Lima MC, Lima RCM, Goulart F. Adaptação do perfil de saúde de Nottingham: um instrumento simples de avaliação da qualidade de vida. Cad Saúde Pública. 2004;20(4):905-14. http://dx.doi.org/10.1590/S0102-311X2004000400004

15. Williamson A, Hoggart B. Pain: a review of three commonly used pain rating scales. J Clin Nurs. 2005;14(7):798-804. http://dx.doi.org/10.1111/j.1365-2702.2005.01121.x

16. Araújo LG, Lima DMF, Sampaio RF, Pereira LSM. Pain Locus of control scale: adaptation and reliability for elderly. Rev Bras Fisioter. 2010;14(5):438-45. http://dx.doi.org/10.1590/S1413-35552010000500014

17. Batistoni SS, Neri AL, Cupertino APFB. Validity of the Center for Epidemiological Studies Depression Scale among Brazilian elderly. Rev Saúde Pública. 2007;41(4):598-605. http://dx.doi.org/10.1590/S0034-89102007000400014

18. Siqueira FB, Teixeira-Salmela LF, Magalhães LC. Analysis of the psychometric properties of the Brazilian version the tampa scale for kinesiophobia. Acta Ortop Bras. 2007;15(1):19-24. http://dx.doi.org/10.1590/S1413-78522007000100004

19. Nusbaum L, Natour J, Ferraz M, Goldenberg J. Translation, adaptation and validation of the Roland-Morris questionnaire - Brazil Roland-Morris. Braz J Med Biol Res. 2001;34(2):203-10.http://dx.doi.org/10.1590/S0100-879X2001000200007
20. Nakano MM. Versão brasileira da Short Physical Performance Battery - SPPB: adaptação cultural e estudo da confiabilidade. [dissertação]. Campinas: Faculdade de Educação, Universidade Estadual de Campinas; 2007.

21. Herdman M, Fox-Rushby J, Badia X. A model of equivalence in the cultural adaptation oh HRQoL instruments: the universalist approach. Qual Life Res. 1998;7(4):323-35. http://dx.doi.org/10.1023/A:1024985930536

22. Beaton DE, Bombardier C, Guillemin F, Ferraz MB. Guidelines for the process of cross-cultural adaptation of self-evaluation measures. Spine. 2000;25(24):3186-91.

23. Landis JR, Koch GG. The measurement of observer agreement for categorical data. Biometrics. 1977;33(1):159-74.

24. Bond TG, Fox CM. Applying the rasch model: fundamental measurement in the human sciences. New Jersey: LawrenceErlbaum; 2001.

25. Fernandes L, Storheim K, Lochting I, Grotle M. Cross-cultural adaptation and validation of the Norwegian pain catastrophizing scale in patients with low back pain. BMC Musculoskeletal Disord. 2012;13:111-20. http://dx.doi.org/10.1186/1471-2474-13-111

26. Yap JC, Lau J, Chen P, Gin T, Wong T, Phil M et al. Validation of the Chinese Pain Catastrophizing Scale (HK-PCS) in patients with chronic pain. Pain Med. 2008;9(2):186-95. http://dx.doi.org/10.1111/j.1526-4637.2007.00307.x

27. Gomes R, Nascimento EF, Araújo FC. Por que os homens buscam menos os serviços de saúde do que as mulheres? As explicações de homens com baixa escolaridade e homens com ensino superior. Cad Saúde Pública. 2007;23(3):565-74. http://dx.doi.org/10.1590/S0102-311X2007000300015

28. Maric A, Banozic A, Cosic A, Kraljevic S, Sapunar D, Puljak L. Validation of the Croatian Pain Catastrophizing Scale through a study on the influence of medical education on pain catastrophizing. Periodicum Biologorum. 2011;113(2):171-5.

29. Meyer K, Sprott H, Mannion AF. Cross-cultural adaptation, reliability, and validity of the German version of the Pain Catastrophizing Scale. J Psychosom Res. 2008;64(5):469-78. http://dx.doi.org/10.1016/j.jpsychores.2007.12.004

30. Vlaeyen JWS, Kole-Snijders AMJ, Rotteveel AM, Ruesnik R, Heuts PHTG. The role of fear of movement/(re)injury in pain disability. J Occupat Rehabilit. 1995;5(4):235-52. http://dx.doi.org/10.1007/BF02109988 
CATASTROPHIZING PAIN SCALE - ADJUSTED VERSION

Escala de catastrofização da dor ajustada para dor lombar aguda em população de meia idade e idosos

Nome:

Idade:

Gênero:

Data:

todas as pessoas passam por situações dolorosas em algum momento de suas vidas. Essas experiências podem incluir dores de cabeça, dores de dente, dores nas articulações ou musculares. As pessoas estão frequentemente expostas a situações que podem causar dor tais como doenças, ferimentos, procedimentos odontológicos ou cirurgia.

\section{Instruções}

Nós estamos interessados nos tipos de pensamentos e sentimentos que o Sr(a) tem quando está com dor. Há treze afirmações abaixo que podem estar associadas à dor. Usando a escala abaixo, por favor indique o grau com que o Sr(a) tem esses pensamentos e sentimentos quando está sentindo dor.

\begin{tabular}{lccccc}
\hline Grau & 0 & 1 & 2 & 3 & 4 \\
\hline Significado & Nada & Leve & Moderado & Intenso & Sempre \\
\hline
\end{tabular}

Quando eu estou com dor...

\begin{tabular}{|l|l|l|}
\hline Número & Afirmação & Grau \\
\hline 1 & Eu fico preocupado o tempo todo se a dor vai terminar. & \\
\hline 2 & Eu sinto que não posso continuar levando a minha vida. \\
\hline 3 & É terrível e eu penso que a dor nunca vai melhorar. \\
\hline 4 & É péssimo e eu sinto que a dor me oprime (ou me deixa desnorteado ou sem rumo). & \\
\hline 5 & Eu sinto que eu não aguento mais. & \\
\hline 6 & Eu fico com medo da dor piorar. & \\
\hline 7 & Eu fico pensando em outros eventos (situações) dolorosos. \\
\hline 8 & Eu fico ansioso para a dor ir embora. & \\
\hline 9 & Eu não consigo parar de pensar na dor. \\
\hline 10 & Eu fico pensando em como dói. & \\
\hline 11 & Eu fico pensando no quanto eu quero que a dor passe. \\
\hline 12 & Não há nada que eu possa fazer para reduzir a intensidade da dor. & \\
\hline 13 & Eu me pergunto se algo de grave pode acontecer. & \\
\hline
\end{tabular}

